\title{
A new national holiday? My vote's for World Toilet Day
}

Previously published at www.cmaj.ca

$\mathrm{N}$ ov. 19, 2009, was World Toilet Day. Before you say, "Who cares?" and flush that idea, consider this: The lack of access to toilets is one of the world's most pressing health problems. And it's a problem that has long been recognized by physicians and other health experts around the world. Almost three years ago, more than 11000 readers of the $B M J$ voted for what they considered to be the most important medical advance in the previous 150 years. Access to clean water and sewage disposal — "the sanitary revolution" - basically cleaned up in this poll, judged the most important medical achievement, over such obvious breakthroughs as antibiotics, anesthesia and vaccines.

In light of this fact, as well as the dishonourable fact that, at the dawn of the 21 st century nearly a third of humanity still doesn't have access to a toilet, I think that the medical community - perhaps spearheaded by Canada's physicians - should be leading the charge to bring some serious public attention to the issue. Several million children, mostly in the developing world, die every year from diseases stemming from poor community hygiene and water. Dysentery, cholera and other serious waterborne disease create an incredible burden of ill health throughout the developing world.

Canadian taxpayers spend upward of $\$ 3$ billion per year on foreign aid, yet aid directed strictly toward solutions that flush get almost nothing. In fact, the Global Sanitation Fund, claimed as one of the best global sanitation initiatives in existence, has never seen Canada contribute a single penny. That stinks.

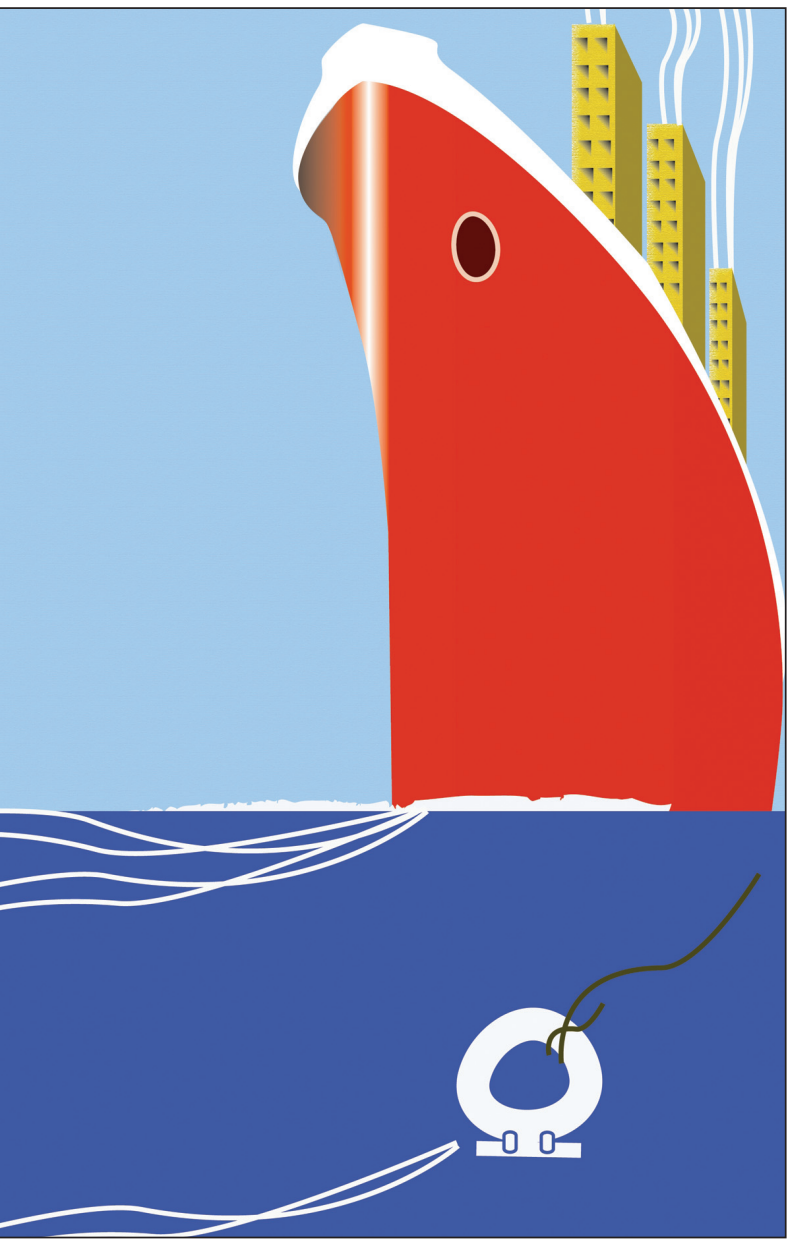

jects. Even a little bit of money goes a long way with a solid, lifesaving community latrine costing as little as a $\$ 100$.

Perhaps attention to this vital health priority, led by Canada's medical community, would put some appropriate pressure on our politicians to "Catch the Sanitation Wave" and devote more of our collective wealth toward these flushable solutions. CMAJ has a track record of publicizing those in the medical community and society who are already doing incredibly valuable medical work overseas, so motivating Canada's medical professionals to be lobbyists for the latrine doesn't seem such a huge stretch.

I think we need to seriously dig into this idea. Why wait, why not start celebrating Canada's new national holiday — World Toilet Day — on our own? Who knows, maybe other countries will follow our upstanding example, and declare World Toilet Day themselves and create attention-gathering events on their own.

The health and lives of mil-

So how does one go about making safe water and access to toilets a more urgent priority on the foreign aid agenda?

For starters, we could lobby the Canadian government to declare World Toilet Day a national holiday, perhaps stick it in the middle of February and maintain its brand as a more pragmatic and grounded version of Valentine's Day, where we could show our respect and love for those in our global neighbourhood who live very different lives than we live.

Maybe we could also use that day to hold an annual sanitation-focused Run for the Bowl, or Rush for the Flush, where we all wear ribbons and run around our cities raising money to build sorely needed overseas sanitation pro- lions of people are at stake. "Toilets for Everyone" should be our mantra!

\section{Alan Cassels MPA \\ Drug policy researcher \\ University of Victoria \\ Victoria, BC}

In the author's city, sewage goes straight into the Strait of Juan de Fuca of the Pacific Ocean. Victoria is also the home to Mr. Floatie, a six-foot, singing, dancing man in a poop suit who has shown us all that putting attention on sanitation can be fun and educational.

Have you got an opinion about this article? Post your views at cmaj.ca. Potential Salon contributors are welcome to send a query to salon@cmaj.ca.

All editorial matter in CMAJ represents the opinions of the authors and not necessarily those of the Canadian Medical Association. 